\title{
所謂虚弱児の夏季生活と体重の関連性
}

\section{Relations between the Summer Life and Body Weights of So-called Delicate Children}

\author{
名古屋大学医学部公衆衞生学教室 (指導 水野宏助教授) \\ 中野 幹 佐藤 文成 後藤 博 寺沢竹三郎
}

Miki Nakano, Fuminari Satô, Hiroshi Gotô, Takesaburô Terazawa

Department of Public Health, Nagoya University School of Medicine

(Director: Ass. Prof. H. Mizuno)

\section{I. 緒 言}

所謂虚弱児の本態掞よびその範疇については，A. O. Heck $^{1)}$, E. W. Dolch ${ }^{21}$ はじめ, 従来幾多の所論があ るが, 元来 “虚弱児”という言葉そのものが医学の場よ り発したものではなく, 教育の場より起つたものである ため, 確然とした定義は下しがたい状態にあつた。

しかし現在に㧧いては教育の現場に抬ける養護上の必 要性に基づいて, 広義の“虚弱者”として疾病児童, 病 弱児童, 疾病・病弱でない狭義の所謂虚弱者の 3 者学含 めたものを虚弱児童として取扱つている。

元来, 体力の消長を 観察するには種々の指標がある が, その中でも体重は諸種の環境因子の軽微な変動によ つても著明な増減を示すために，もつとも普遍的で客観 的に明確に把握しうる目標となる。

殊に夏季は, 健康な児童に掞いても体重増加の消極 性ないしは減少を示すものであるが, 環境適応能力の拙 劣な“虚弱児”はどのような体重の消長を示すものであ ろうか，また虚弱学童の夏季休㗇中のごのような生活状 況が体重変化に重要な役割を演ずるものであるうかとい 了点について検討し， 2,3 の知見を得たので報告す る。

\section{II. 研究資料および研究方法}

昭和 29 年度愛知県下 (名古屋市を除く) において, 養 護学級を編成する小学校 23 校の満 6 才の児童, 男子 279 名, 女子 306名, 合計 585名在研究対象とした。なお対 象校に招ける満 6 才の総在籍児童数怯男子 2,821 名, 女 子2,595 名, 計 5,416 名である。

対象校に执いては養護を要する児童の選定に多くは文 部省のl湿弱児選定基潐 ${ }^{3}$ を参考とし，学校医，担任教 官, 保健主事, 養謢教官の総合判定捛よび览童家族の希 望考考慮して行つているので, 本調查対象は広義の虚弱 児，即ち要養護児童を含むととになる。

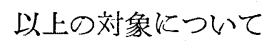

\section{（1）巷臂学級編入理由}

\section{(2) 体重測定}

7. 月末日拉よび 9 月 1 日に午前10時を期し, 体重測定 に関する諸種の注意事項”を簃守して型のごとく体重測 定を行い, 夏季休㗇中における体重の増減を調査した。

\section{(3) 生活調查}

調查の正確を期するためあらかじめ熟練せる保健主事 養護教官, 担任教官と調査前に打合せ, 検討, 指導を行 い, 調查方法につき万全の処置を講じたのち, 調査用紙を 配布し, 体重増減に顕著を影響を有すると推察される休 暇中に扔ける生活状況, 即与起床時刻, 就床時刻, 睡眠 時間, 午睡時間, 便通 (普通便, 水様下痢, 1 日の下痢 回数, 下痢持続期間), 食欲, 疾病 (疾病の種類, 持続期 間), 発熱状況 (持続日数, 最高体温), 水泳時間および回 数, 夜ふかし(持続日数, 最終時刻, 種類), 盆踊り, 全 身状態などにつき，児童抢よびその家庭と密接なる連絡 をとり，その都度日記風に詳細にわたり記入せしめた。

以上によつて得た資料のうち，1 項目であ不正確な記 載のあるものは捨て, 男子 228 名, 女子 234 名, 計 462 名を得たので, 休㗇中の生活状況につき体重増加群と体 重減少群との間に $x^{2}$ 検定および睡眠時間については平 均值の比較 (5) -7) 行つた。

\section{III. 研究成績}

本調查対象の養護学級児童数男子 279 名，女子 306 
第 1 表 意級編入理由

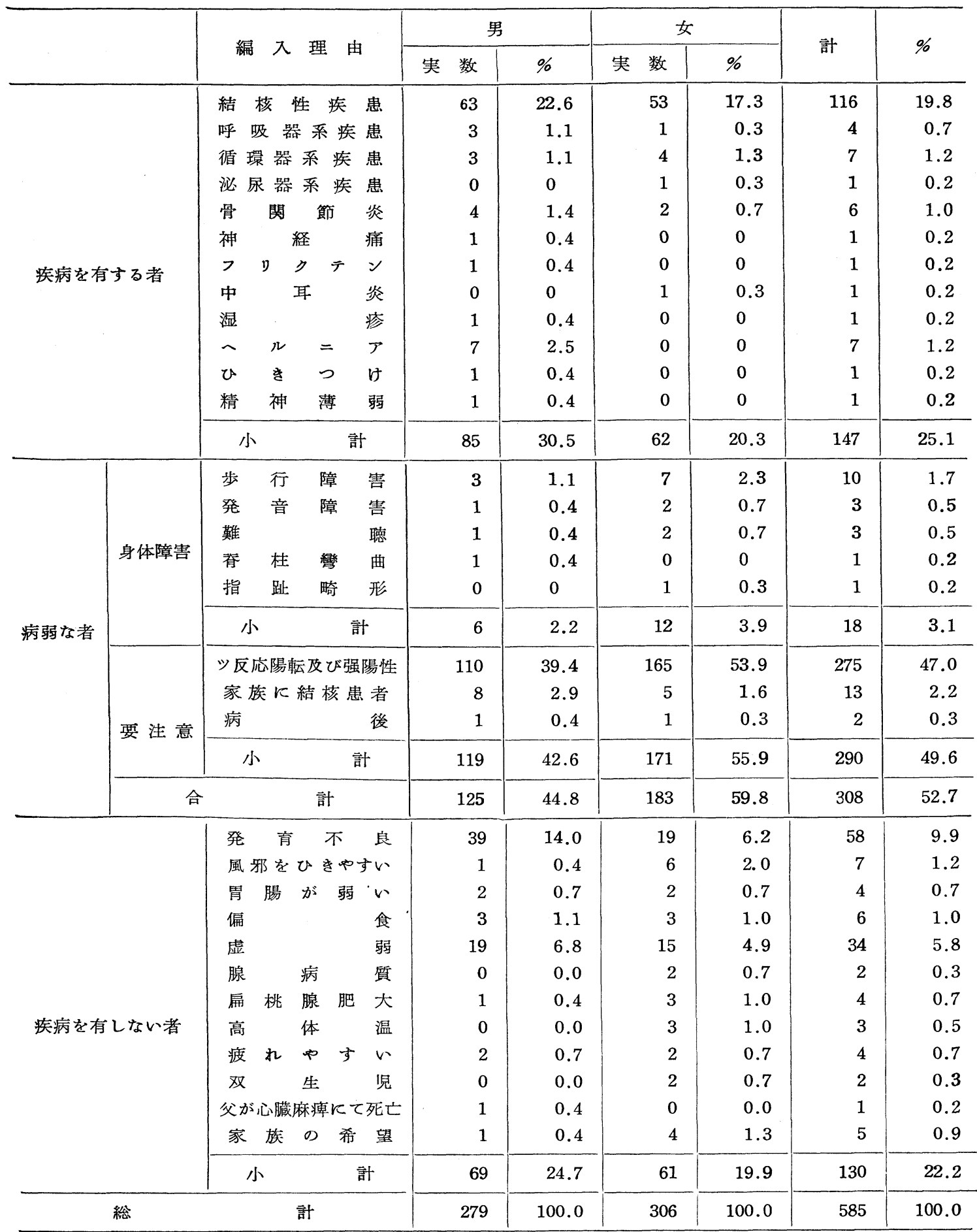


名, 計 585 名虫, 対象校の同一年令総在籍児童数男子 2,821 名, 女子 2,595 名, 計5,416 名に対し, 男子 11.3 $\%$, 女子 $11.8 \%$, 計 $11.6 \%$ となり諸家の成績とほぼ一致 する7) 8)

養護学級編入理由抢よびその百分率は第 1 表のごとく であり,てれを有疾病児童, 病弱児童, 疾病を有しない 狭義の虚弱児童に分つを, 有疾病児童は男子85名, 女子 62名，計 147 名となり，全養護学級児のそれぞれ 30.5 $\%, 20.3 \%$, 計 $25.1 \%$ にあたる。結核要注意者を含む病 弱児童は男子 125 名, 女子 183 名, 計 308 名となり, 全 養護学級児のそれぞれ $44.8 \%$ ，59.8\%，計 $52.6 \%$ にあた る。

疾病を有しない狭義の虚弱児は男69名, 女子 61 名, 計 130名で，全養護学級児のそれぞれ $24.7 \% ， 19.9 \%$, 計 $22.2 \%$ にあたり相当高率である。

昭和 29 年 7 月末日捛よび 9 月 1 日に招ける体重の標本 平均抢よび標準偏差は第 2 表のごとくであり, 男子は休 㗇前に比して体重減少を示すが, 女子では僅かな体重増 加を示している。推計学的と7月值と 9 月值との差を検 定すると，いずれも有意の差を証明しない。

体重増加者, 減少者, 不変者の男女別度数分布捛よび その百分率は第 3 表のごとくである。

\section{第 2 表 夏期休睱前後における体重} 平均および標準偏差

\begin{tabular}{|c|c|c|c|c|c|c|}
\hline \multirow{2}{*}{\multicolumn{2}{|c|}{ 性 測定日 }} & \multirow[b]{2}{*}{$\mathrm{N}$} & \multicolumn{2}{|c|}{7 月末日 } & \multicolumn{2}{|c|}{9 月 1 日 } \\
\hline & & & $\overline{\mathrm{x}}$ & $\sigma$ & $\overline{\mathrm{x}}$ & $\sigma$ \\
\hline & 男 & 279 & 18.5 & 3.9 & 18.4 & 3.9 \\
\hline & 女 & 306 & 18.0 & 4.1 & 18.1 & 4.1 \\
\hline
\end{tabular}

第 3 表 体重增減者の比較

\begin{tabular}{|c|c|c|c|c|c|c|c|c|}
\hline & 増加 & $\%$ & 減少 & $\%$ & \begin{tabular}{|l|} 
増減 \\
なし
\end{tabular} & $\%$ & 計 & $\%$ \\
\hline & 127 & 43.4 & 101 & 36.2 & 57 & 20 . & 279 & 100.0 \\
\hline 女 & 145 & 47.4 & 97 & 31.7 & 64 & 20.9 & 306 & 100.0 \\
\hline 計 & 266 & 45.5 & 198 & 33.8 & 121 & 20.7 & 585 & 100.0 \\
\hline
\end{tabular}

養護学級児の夏季休㗇中に抬ける生活状況の男女別度 数分布捛よび百分率は第 4 表 $(1)$ (12) 抢よび第 1 図 (1)～(12)の分布図のどとくであり，それぞれについて 検討すると，

\section{1) 起床時刻}

男女ともほ济同し傾向を示し，もつとも早い者は午前
4 時より 5 時の間に起床し，もつとも遅い者は午前 9 時 より10眭の間に起床する。大部分の者は午前 6 時より 7 時の間で, 男子 144名 (62.7\%), 女子 152名 (65.0\%), ついで午前 5 時より 6 時の者が男子 50 名 (21.9\%), 女子 48 名 $(20.5 \%)$, 次に午前 7 時より 8 蛙の者が多く男子 28 名 $(12.3 \%)$, 女子 21 名 $(12.4 \%)$ となり, 他の時刻の者 は少数である。

第 4 表（1）起床時刻

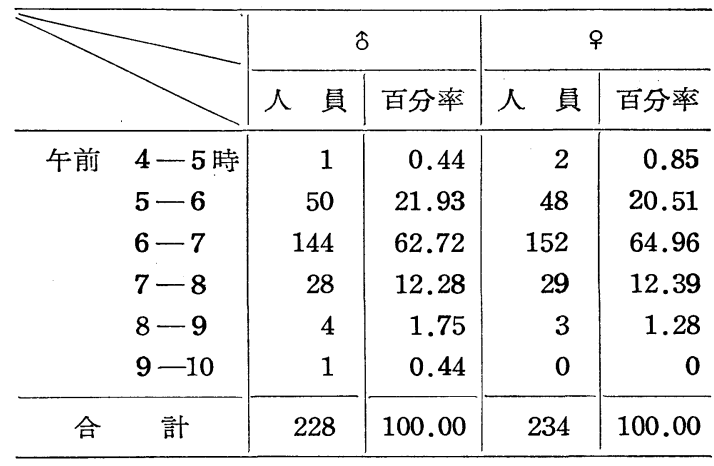

第 1 図（1）起床時刻

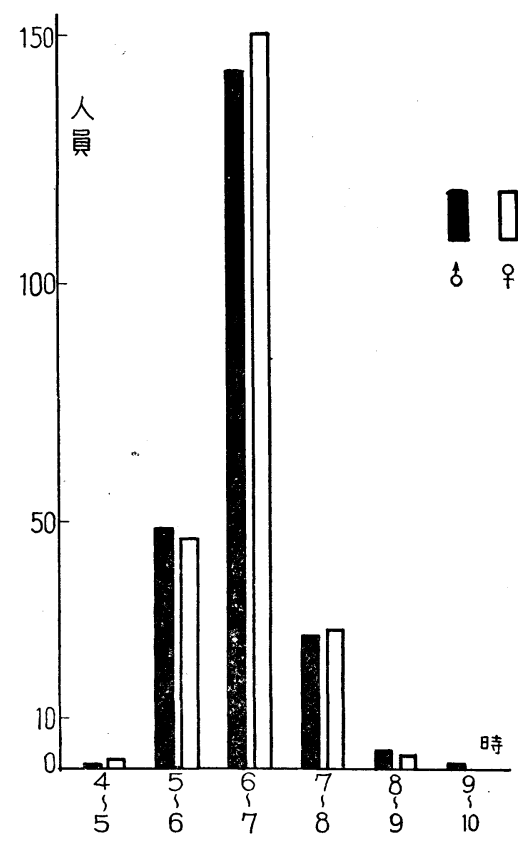

\section{2) 就床時刻}

午後 6 時より 7 時に就床する者をはじめとしてもつを も遅い者は午後10時より11時の間である。午後 8 時より 9 時の者がもつとも多く, 男子 139 名(61.0\%), 女子 143 名 $(61.1 \%)$ を占め, ついで午後7 時より 8 時の者が多 
く,男子51名 (22.4\%),女子 45 名 $(19.2 \%)$ となり,第 3 位は午後 9 時より 10 時の間の者が男子 35 名 (15.4\%),女 子38名 (16.2\%) となる。その他の時間の者は少ない。

第 4 表（2）就床時刻

\begin{tabular}{|c|c|c|c|c|c|}
\hline & \multicolumn{2}{|c|}{$\hat{\delta}$} & \multicolumn{2}{|c|}{ q } \\
\hline & & 人 員 & 百分率 & 人 員 & 百分率 \\
\hline \multirow[t]{5}{*}{ 午後 } & $6-7$ 時 & 2 & 0.88 & 5 & 2.14 \\
\hline & $7-8$ & 51 & 22.37 & 45 & 19.23 \\
\hline & $8-9$ & 139 & 60.96 & 143 & 61.11 \\
\hline & $9-10$ & 35 & 15.35 & 38 & 16.24 \\
\hline & $10-11$ & 1 & 0.44 & 3 & 1.28 \\
\hline 合 & 計 & 228 & 100.00 & 234 & 100.00 \\
\hline
\end{tabular}

第 1 図（2）就床時刻

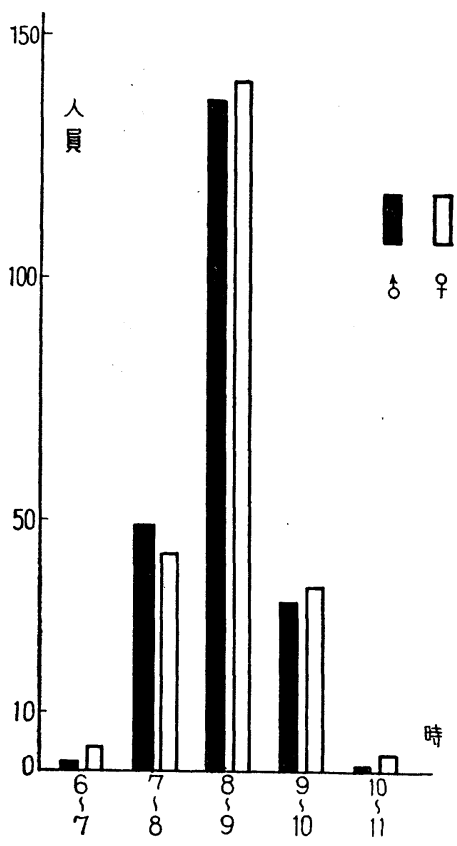

\section{3) 睡眠時間}

1 日のうち午睡時間を含まない夜間の睡眠時間として もつとも少なくとる者は 7 時間, 最多の者は14時間てあ り，大部分の者は 10 時間でる。即ち10時間の睡眠を己 る者は男子 102名 (44.7\%), 女子 104 名 (44.4\%) て もつとも多く，ついて9時間の者が男子59名 (25.9\%), 女子 64 名 $(27.4 \%)$, 第 3 位は11時間で男子 43 名 (18.9 \%),女子 40 名 $(17.1 \%)$ となる。
第 4 表（3）睡眠時間

\begin{tabular}{|c|c|c|c|c|}
\hline & \multicolumn{2}{|c|}{$\hat{o}$} & \multicolumn{2}{|c|}{ 우 } \\
\hline & 人 員 & 百分率 & 人 員 & 百分率 \\
\hline 7 時間 & 3 & 1.32 & 1 & 0.43 \\
\hline 8 & 11 & 4.82 & 20 & 8.55 \\
\hline 9 & 59 & 25.88 & 64 & 27.35 \\
\hline 10 & 102 & 44.74 & 104 & 44.44 \\
\hline 11 & 43 & 18.86 & 40 & 17.09 \\
\hline 12 & 4 & 1.75 & 5 & 2.14 \\
\hline 13 & 1 & 0.44 & 0 & 0 \\
\hline 14 & 5 & 2.19 & 0 & 0 \\
\hline 合 計 & 228 & 100.00 & 234 & 100.00 \\
\hline
\end{tabular}

第 1 図（3）睡眠時間

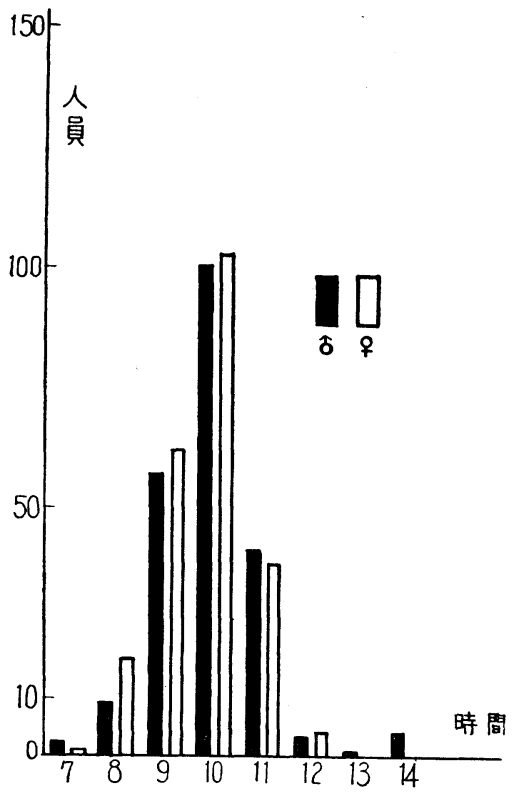

\section{4) 午睡時間}

午睡学行わ好者は男子 147 名 (64.5\%), 女子 131 名 (56.0\%) で, 養護学級児でも午睡の習慣はあまり行わ れていない。午睡をこる者では30分より 1 時間の者が男 女とももつとも多く男子 33 名 (14.5\%), 女子 42 名 (18.0 $\%$ である。1 時間より 2 時間の者も比較的多く男子 31 名 $(13.6 \%)$,女子 34 名 $(14.5 \%)$ である。

\section{5) 便 通}

普通便の者（下淑をしない者）が男子 199 名 (87.3 $\%)$,女子 216 名 (92.3\%) で大部分を占めるが，下㢉を した者は男子 29 名 (12.7\%),女子18名 ( $7.7 \%)$ で比較 
第 4 表（4）午睡時間

\begin{tabular}{|c|c|c|c|c|}
\hline & \multicolumn{2}{|c|}{$\hat{o}$} & \multicolumn{2}{|c|}{$q$} \\
\hline & 人 員 & 百分率 & 人 員 & 百分率 \\
\hline 0 & 147 & 64.47 & 131 & 55.98 \\
\hline 30 分以内 & 17 & 7.46 & 27 & 11.54 \\
\hline 30 分-1時間 & 33 & 14.47 & 42 & 17.95 \\
\hline 1 時間一 2 時間 & 31 & 13.60 & 34 & 14.53 \\
\hline 計 & 81 & 35.53 & 103 & 44.02 \\
\hline 合 & 228 & 100.00 & 234 & 100.00 \\
\hline
\end{tabular}

第 1 図（4）午睡時間

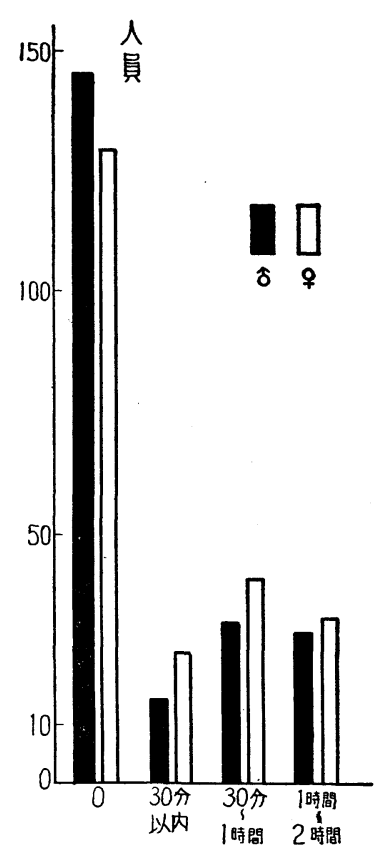

的少ない。下淑をした者のうち，その継続日数は 2 日の 者がもつをも多く男子 13 名 ( $5.7 \%)$, 女子 6 名 ( 2.6 \%) て, ついで1日の者が男子 7 名 ( $3.1 \%)$, 女子 4 名 $(1.7 \%)$ であつて, 他は少数であるが，7日間継続 する者も男子 4 名 ( $1.8 \%)$,女子 3 名 ( $1.3 \%)$ ある。

1 日の下峲回数では， 3 回の者がもつとも多く男女そ れぞれ13名, 7 名て, ついで 4 回〜 5 回の者が多い。

\section{6) 直 欲}

休暇中いつも良好な者は男子 145 名 $(63.6 \%)$, 女子 140名 (59.8\%) で過半数を示し, 良好な者が多いが, 休 层中いつも良くない者，時に不良な者，絶対不良な者を 含めた食欲良好でない者も，男子83名 (36.4\%),女子94

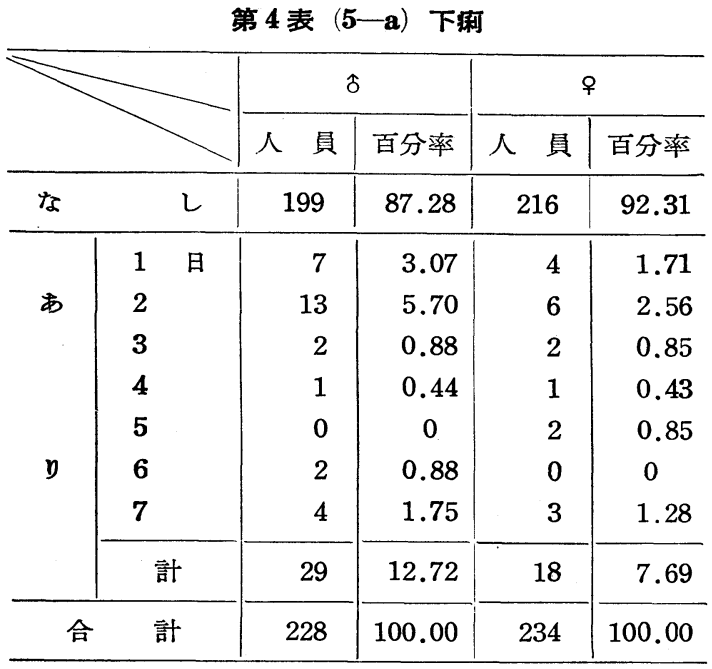

第1図（5-a）下琍

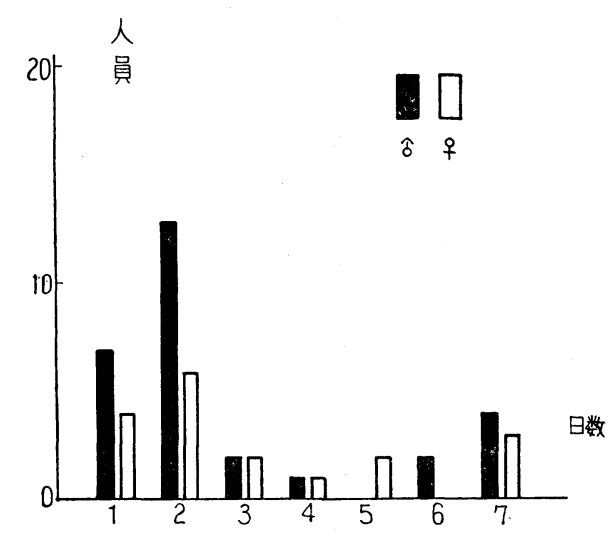

第 4 表（5-b） 1 日の下粕回数

\begin{tabular}{|c|c|c|c|}
\hline 回数 & & $\hat{o}$ & 우 \\
\hline & 1 回 & 1 & 3 \\
\hline & 2 & 2 & 3 \\
\hline & 3 & 13 & 7 \\
\hline & 4 & 6 & 4 \\
\hline & 5 & 6 & 3 \\
\hline & 6 & 0 & 0 \\
\hline & 7 & 0 & 1 \\
\hline 不 & 明 & 1 & 0 \\
\hline
\end{tabular}

名 $(40.2 \%)$ と養護学級児の環境刺战に対する被影響性 の敏感さを示している。 
第 1 図（5-b） 1 日の下浰回数

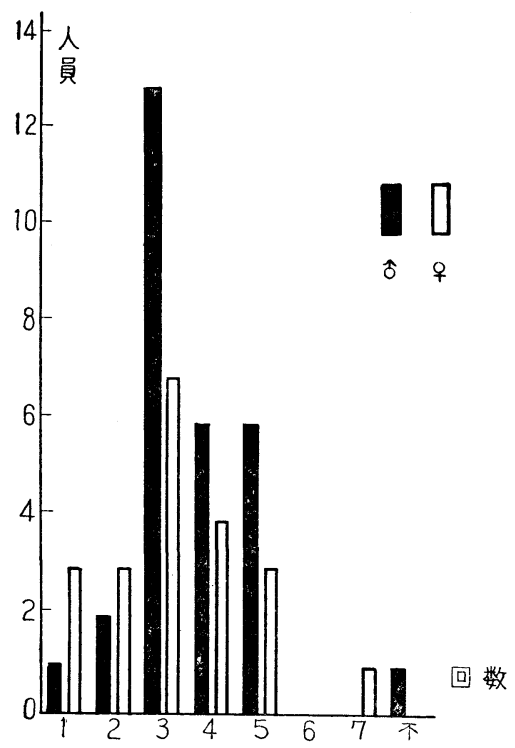

第 4 表（6）食 欲

\begin{tabular}{|c|c|c|c|c|}
\hline & \multicolumn{2}{|c|}{$\hat{o}$} & \multicolumn{2}{|c|}{ 웅 } \\
\hline & 人 員 & 百分率 & 人 員 & 百分率 \\
\hline $\begin{array}{l}\text { 良 好 } \\
(\text { 如良い) }\end{array}$ & 145 & 63.60 & 140 & 59.83 \\
\hline $\begin{array}{l}\text { 不良(いつも } \\
\text { 良くない) } \\
\text { やゃ 不 良 }\end{array}$ & 6 & & 8 & \\
\hline (時々不良) & 75 & 32.89 & 86 & 36.75 \\
\hline 絶 対不良 & 2 & 0.88 & 0 & 0 \\
\hline 計 & 83 & 36.40 & 94 & 40.17 \\
\hline 合 & 228 & 100.00 & 100.00 & 234 \\
\hline
\end{tabular}

7) 疲 病

疾病にかからない者は男子 165 名 (72.4\%),女子 191 名 $(81.6 \%)$ で大部分点める。疾病にかかつた者は男 子63名 $(27.6 \%)$, 女子 43 名 $(18.4 \%)$ でり, 疾病罹患 者も比較的多いととがわかる。

疾病の罹患期間は $1 \sim 3$ 日の者が大部分で男子 41 名 (18.9\%), 女子 30 名 $(12.8 \%)$ であるが, 中には少数で あるが30日間の長期にわたる者もある。

罹患した疾病分類は第 4 表（7一b）のごとくであるが 呼吸器系, 消化器系疾患が多く, 中でも風邪が男子17名 女子12名で大部分を占める。しかしその範囲が非常に広 く各種疾患に罹患するとともわかる。
第 1 図 $(6)$ 食 欲

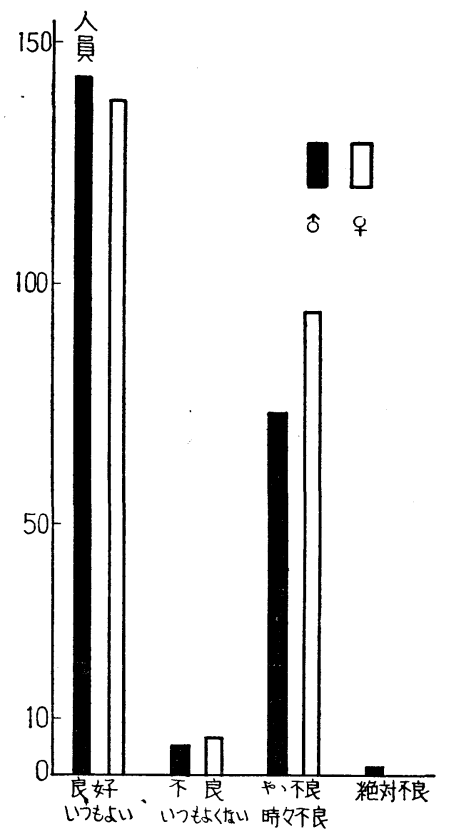

第 4 表 $(7-a)$ 㢍 病

\begin{tabular}{|c|c|c|c|c|c|}
\hline & & \multicolumn{2}{|c|}{$\hat{o}$} & \multicolumn{2}{|c|}{ 우 } \\
\hline & & 人 員 & 百分率 & 人 員 & 百分率 \\
\hline な & L & 165 & 72.37 & 191 & 81.62 \\
\hline & 半日 & 2 & 0.88 & 0 & 0 \\
\hline & 1 & 18 & 7.89 & 10 & 4.27 \\
\hline & 2 & 15 & 6.58 & 10 & 4.27 \\
\hline & 3 & 8 & 3.51 & 10 & 4.27 \\
\hline & 4 & 5 & 2.19 & 3 & 1.28 \\
\hline & 5 & 6 & 2.63 & 2 & 0.85 \\
\hline & 6 & 1 & 0.44 & 1 & 0.43 \\
\hline & 7 & 3 & 1.32 & 1 & 0.43 \\
\hline & 8 & 0 & 0 & 0 & 0 \\
\hline & 9 & 0 & 0 & 1 & 0.43 \\
\hline & 10 & 2 & 0.88 & 4 & 1.71 \\
\hline & 15 & 1 & 0.44 & 0 & 0 \\
\hline & 30 & 2 & 0.88 & 1 & 0.43 \\
\hline & 計 & 63 & 27.63 & 43 & 18.38 \\
\hline 合 & 計 & 228 & 100.00 & 234 & 100.00 \\
\hline
\end{tabular}


第 1 図（7）疾

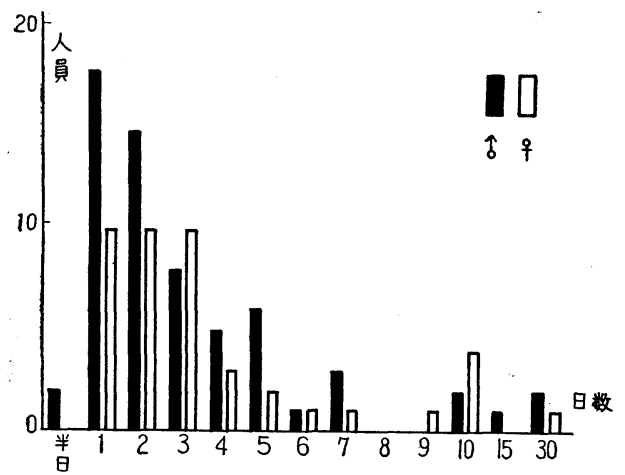

第 4 表 $(7-b)$ 㾜病分類

\begin{tabular}{|c|c|c|c|c|c|c|c|}
\hline & & $\hat{\delta}$ & ㅇ & & & $\hat{\delta}$ & 우 \\
\hline \multirow{5}{*}{$\begin{array}{l}\text { 呼 } \\
\text { 吸 } \\
\text { 器 } \\
\text { 采 } \\
\text { 疾 }\end{array}$} & 風 邪 & 17 & 12 & $\begin{array}{l}\text { 染 } \\
\text { 性 }\end{array}$ & 猩 紅 熱 & 1 & 0 \\
\hline & 扁桃腺炎 & 4 & 2 & 疾患 & 水 痘 & 0 & 1 \\
\hline & 気管支炎 & 2 & 1 & \multirow{3}{*}{ そ } & \multirow{3}{*}{$\begin{array}{c}\text { 心 疾 患 } \\
\text { 眼 疾 } \\
\text { 鼻 } \\
\text { 出 血 }\end{array}$} & \multirow{3}{*}{$\begin{array}{l}1 \\
1 \\
1\end{array}$} & \multirow{3}{*}{$\begin{array}{l}0 \\
1 \\
0\end{array}$} \\
\hline & 肺 浸 潤 & 2 & 0 & & & & \\
\hline & 助 膜 炎 & 0 & 1 & & & & \\
\hline & 下 & 1 & 1 & \multirow[t]{2}{*}{ の } & アデノイド & 0 & 1 \\
\hline 消 & 痛 & 4 & 4 & & 皮膚疾患 & 1 & 0 \\
\hline 化 & 炎 & 0 & 4 & \multirow[t]{2}{*}{ 他 } & 畨 & 1 & 0 \\
\hline 器 & 大腸カタル & 3 & 0 & & 寝 冷 え & 2 & 2 \\
\hline 系 & 食へすす & 1 & 0 & \multirow[t]{2}{*}{ の } & 不 明 熱 & 2 & 0 \\
\hline 疾 & 食 中 & 2 & 1 & & 痛 & 1 & 2 \\
\hline \multirow[t]{2}{*}{ 患 } & 回 & 0 & 1 & \multirow[t]{2}{*}{ 疾 } & 日 射 病 & 1 & 1 \\
\hline & 虫 & 0 & 1 & & 䕃 麻 疹 & 0 & 2 \\
\hline \multirow{3}{*}{$\begin{array}{l}\text { 外 } \\
\text { 科 } \\
\text { 的 } \\
\text { 疾 } \\
\text { 患 }\end{array}$} & \multirow{3}{*}{$\begin{array}{l}\text { 脱 腸 } \\
\text { 虫 垂 炎 } \\
\text { 淋巴腺 炎 }\end{array}$} & \multirow{3}{*}{1} & \multirow{3}{*}{$\begin{array}{l}0 \\
0 \\
1\end{array}$} & \multirow[t]{2}{*}{ 患 } & \multirow{2}{*}{$\begin{array}{l}\text { 寝 } \\
\text { 原因不明 }\end{array}$} & \multirow{2}{*}{$\begin{array}{l}1 \\
9\end{array}$} & \multirow{2}{*}{$\begin{array}{l}0 \\
0\end{array}$} \\
\hline & & & & & & & \\
\hline & & & & & \multirow{3}{*}{ 合計 } & \multirow{3}{*}{63} & \multirow{3}{*}{41} \\
\hline $\begin{array}{l}\text { 急 } \\
\text { 性 }\end{array}$ & 八シ カ & 2 & 0 & & & & \\
\hline 伝 & 百 日 喛 & 0 & 2 & & & & \\
\hline
\end{tabular}

\section{8) 発 悬}

発熱なき者は男子 177 名 (77.6\%),女子 195名 (83.3 \%) て大部分を占め, 発熱せし者は男子51名 (22.4\%), 女子39名 $(16.7 \%)$ である。発熱の持続期間は 1 日の者 がもつとも多く男子 20 名 ( $8.8 \%$ ), 女子 12 名 ( $5.1 \%$ ), ついて 2 日，3日となつている。しかし中には15日から 30 日と比較的長く続いた者も $1 ， 2$ 名ある。

1 日の最高体温は $37 \sim 39^{\circ} \mathrm{C}$ 者が多く, 微熱ないし中 等度発熱の者が大部分てある。

15日〜30日間の長期発熱者の体温は $37.2 \sim 37.8^{\circ} \mathrm{C}$ 程度
表 4 表 $(8$ - - $)$ 発 鮉

\begin{tabular}{|c|c|c|c|c|c|}
\hline & & \multicolumn{2}{|c|}{$\hat{o}$} & \multicolumn{2}{|c|}{ q } \\
\hline & & 人 員 & 百分率 & 人 員 & 百分率 \\
\hline \multirow[t]{13}{*}{ な } & L & 177 & 77.63 & 195 & 83.33 \\
\hline & 半日 & 1 & 0.44 & 0 & 0 \\
\hline & 1 & 20 & 8.77 & 12 & 5.13 \\
\hline & 2 & 13 & 5.70 & 11 & 4.70 \\
\hline & 3 & 9 & 3.95 & 7 & 2.99 \\
\hline & 4 & 1 & 0.44 & 2 & 0.85 \\
\hline & 5 & 3 & 1.32 & 3 & 1.28 \\
\hline & 6 & 2 & 0.88 & 0 & 0 \\
\hline & 7 & 0 & 0 & 2 & 0.85 \\
\hline & 8 & 0 & 0 & 1 & 0.43 \\
\hline & 15 & 1 & 0.44 & 1 & 0.43 \\
\hline & 30 & 1 & 0.44 & 0 & 0 \\
\hline & 計 & 51 & 22.37 & 39 & 16.67 \\
\hline 合 & 計 & 228 & 100.00 & 234 & 100.00 \\
\hline
\end{tabular}

第1図 (8一a) 発 熱

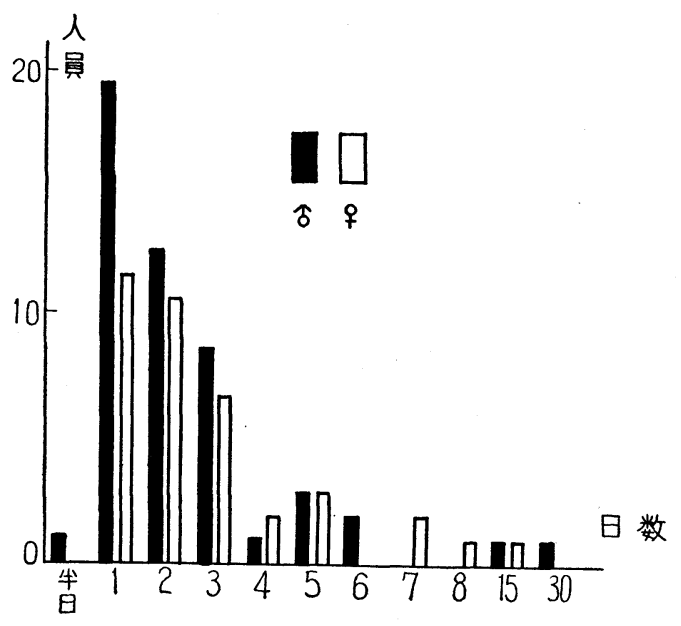

第 4 表（8-b） 1日の最高体温

\begin{tabular}{l|r|r}
\hline 体 温 & \& & \multicolumn{1}{|c}{ 우 } \\
\hline $36 \sim 37^{\circ} \mathrm{C}$ & 3 & 3 \\
$37 \sim 38$ & 28 & 19 \\
$38 \sim 39$ & 15 & 16 \\
$39 \sim 40$ & 5 & 1 \\
\hline 計 & 51 & 39 \\
\hline
\end{tabular}

で, 疾病と心関係をみると, ツ反応陽転括よひ結核性疾 患との関係はなく，小児の高体温症を思わせる。 
第1 図 (8一b) 1 日の最高体温

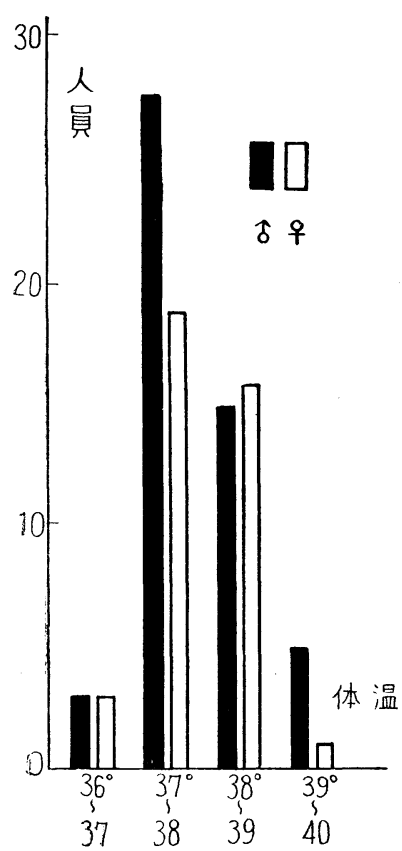

9) 水 泳

水泳を全然行わない者が男子 153 名 $(67.1 \%)$, 女子 169 名 $(72.2 \%)$ で, 大半の者が 水泳を行わないよう である。水泳を行つた者は男子75名 (32.9\%),女子65名 (27.8\%) で, 地域的に海岸, 河川, プール等に近〉水 泳浭利な者がしばしば行う傾向にある。

水泳時間は大部分の者が 30 分以内, 長くとも 1 時間で あるが，さらにそれ以上の者も男子19名 ( $8.3 \%)$,女子 9 名 $(3.8 \%)$ ある。

第 4 表 $(9)$ 水 泳

\begin{tabular}{|c|c|c|c|c|}
\hline & \multicolumn{2}{|c|}{ o } & \multicolumn{2}{|c|}{ 우 } \\
\hline & 人 員 & 百分率 & 人 員 & 百分率 \\
\hline な し & 153 & 67.10 & 169 & 72.22 \\
\hline 30 分 以 内 & 32 & 14.03 & 30 & 12.82 \\
\hline 30分-1 時間 & 24 & 10.53 & 26 & 11.11 \\
\hline 1時間一2時間 & 15 & 6.58 & 8 & 3.42 \\
\hline 2 時間以上 & 4 & 1.75 & 1 & 0.43 \\
\hline 計 & 75 & 32.89 & 65 & 27.78 \\
\hline 計 & 228 & 100.00 & 234 & 100.00 \\
\hline
\end{tabular}

第1図（9）水泳

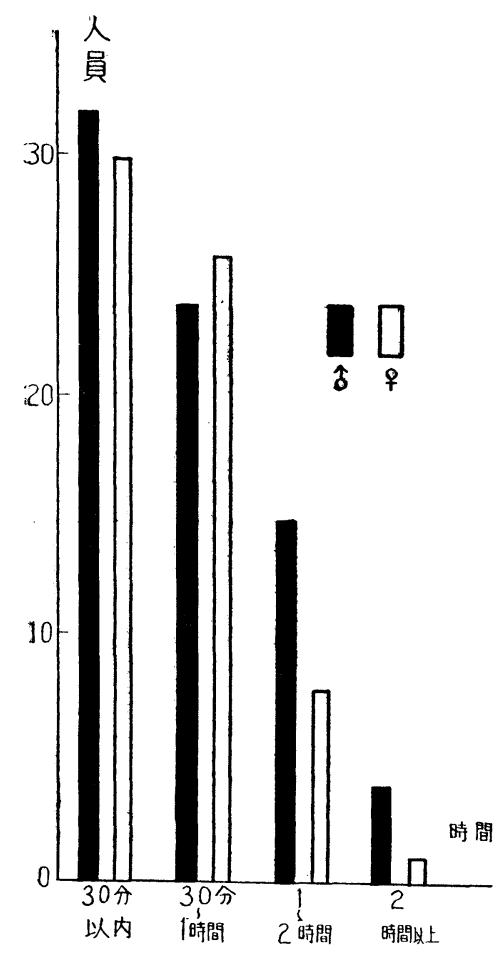

\section{0）盆踊り}

全然行わ奴者男子 189名 (82.9\%), 女子 136名 (58.1 \%) で大部分を占め, 行う者は男子 39 名 (17.1\%), 女子 98名 $(41.9 \%)$ で女子信率であり，継続期間は大半は 1 〜 3 日であるが, 地域によつては10日ないし25日にわ たるものも数名ある。

終了の最終時刻は午後 9 時〜10時であるが, 午後 12 時 より午前 2 時化及んだ者も $1 ， 2$ ある。

\section{1) 夜ふかし}

本調查では対象の年令などを考虑し, 他律的に何時以 後を夜ふかしとするというような規定を避け, 本人の自 覚的判断によつた。乞れが, ありの恋の状況学知当た めに役立つたと思う。

夜ふ玑ししたと思わ奴者男子 157 名 $(68.9 \%)$, 女子 162名 $(69.2 \%$ ) で, 夜ふかしをしたと思う者であその 日数は大部分の者は $1 \sim 3$ 日くらいである。女子に夜ふ かしの傾向がある。

最終の㭙刻は大部分午後10時〜11時であり, その原因 は第 4 表 $(11-c)$ のごとく, 映画, 盈踊り执よびその 見物が多い。

\section{2）全身状態}


第 4 表 $(10-a)$ 盆踊り（日数）

\begin{tabular}{|c|c|c|c|c|c|}
\hline & & \multicolumn{2}{|c|}{$\hat{o}$} & \multicolumn{2}{|c|}{ 우 } \\
\hline & & 人 員 & 百分率 & 人 員 & 百分率 \\
\hline \multirow[t]{16}{*}{ な } & ᄂ & 189 & 82.89 & 136 & 58.12 \\
\hline & 1 日 & 5 & 2.19 & 10 & 4.27 \\
\hline & 2 & 12 & 5.26 & 10 & 4.27 \\
\hline & 3 & 6 & 2.63 & 11 & 4.70 \\
\hline & 4 & 2 & 0.88 & 7 & 2.99 \\
\hline & 5 & 4 & 1.75 & 16 & 6.84 \\
\hline & 6 & 0 & 0 & 2 & 0.85 \\
\hline & 7 & 2 & 0.88 & 22 & 9.40 \\
\hline & 8 & 1 & 0.44 & 1 & 0.43 \\
\hline & 9 & 0 & 0 & 1 & 0.43 \\
\hline & 10 & 6 & 2.63 & 11 & 4.70 \\
\hline & 12 & 0 & 0 & 3 & 1.28 \\
\hline & 13 & 0 & 0 & 1 & 0.43 \\
\hline & 15 & 0 & 0 & 3 & 1.28 \\
\hline & 25 & 1 & 0.44 & 0 & 0 \\
\hline & 計 & 39 & 17.11 & 98 & 41.88 \\
\hline 合 & 計 & 228 & 100.00 & 234 & 100.00 \\
\hline
\end{tabular}

第 1 図 $(10-a)$ 盆踊り（日数）

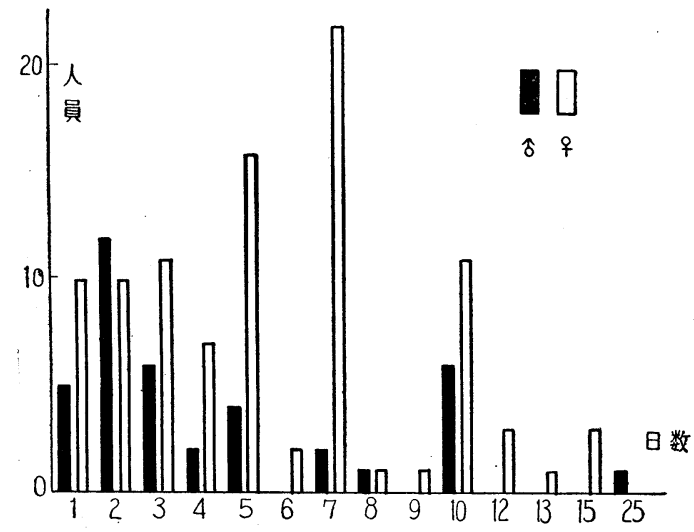

第 4 表 $(10$-b) 盆踊り（終了時刻）

\begin{tabular}{|c|c|c|}
\hline & $\hat{\delta}$ & 우 \\
\hline 8 時 & 1 & 5 \\
\hline 8 時半 & 2 & 18 \\
\hline 9 時 & 14 & 43 \\
\hline 10 & 15 & 29 \\
\hline 11 & 1 & 3 \\
\hline 12 & 1 & 0 \\
\hline 1 & 0 & 0 \\
\hline 2 & 1 & 0 \\
\hline 不 明 & 4 & 0 \\
\hline 合 計 & 39 & 98 \\
\hline
\end{tabular}

第 1 図 (10-b) 盆踊り（終了時刻）

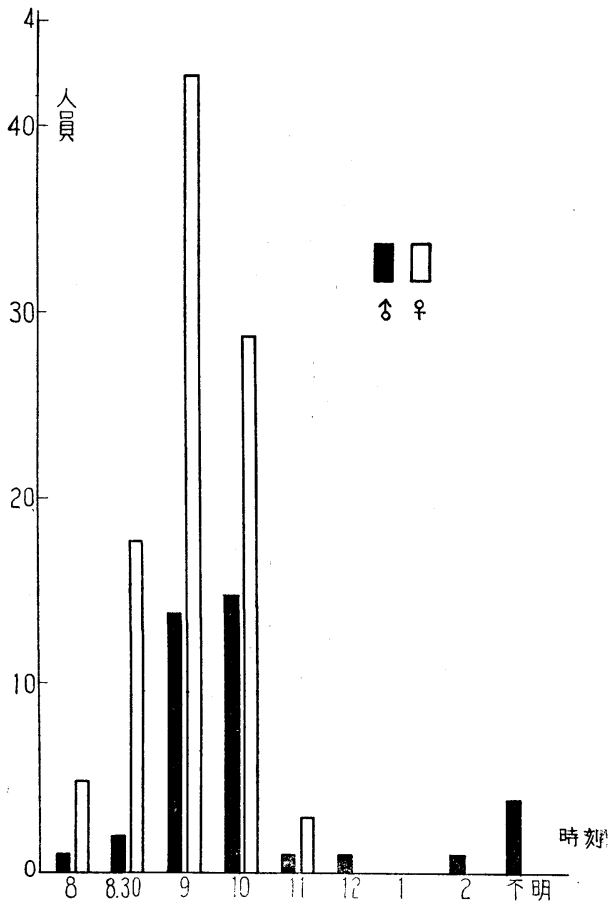

第 4 表（11一a）夜ふかし

\begin{tabular}{|c|c|c|c|c|c|}
\hline & & \multicolumn{2}{|c|}{$\hat{o}$} & \multicolumn{2}{|c|}{ क } \\
\hline & & 人 員 & 百分率 & 人 員 & 百分率 \\
\hline \multirow[t]{16}{*}{ な } & ᄂ & 157 & 68.86 & 162 & 69.23 \\
\hline & 1 日 & 12 & 5.26 & 16 & 6.84 \\
\hline & 2 & 21 & 9.21 & 15 & 6.41 \\
\hline & 3 & 20 & 8.77 & 10 & 4.27 \\
\hline & 4 & 4 & 1.75 & 6 & 2.56 \\
\hline & 5 & 8 & 3.51 & 7 & 2.99 \\
\hline & 6 & 0 & 0 & 1 & 0.43 \\
\hline & 7 & 1 & 0.44 & 4 & 1.71 \\
\hline & 8 & 0 & 0 & 1 & 0.43 \\
\hline & 9 & 0 & 0 & 0 & 0 \\
\hline & 10 & 5 & 2.19 & 8 & 3.42: \\
\hline & 12 & 0 & 0 & 1 & 0.43 : \\
\hline & 13 & 0 & 0 & 1 & 0.43 \\
\hline & 14 & 0 & 0 & 1 & 0.43 \\
\hline & 23 & 0 & 0 & 1 & 0.43 \\
\hline & 計 & 71 & $31: 14$ & 72 & 30.77 \\
\hline 合 & 計 & 228 & 100.00 & 234 & 100.00 \\
\hline
\end{tabular}


第 1 図（11一a）夜ふかし

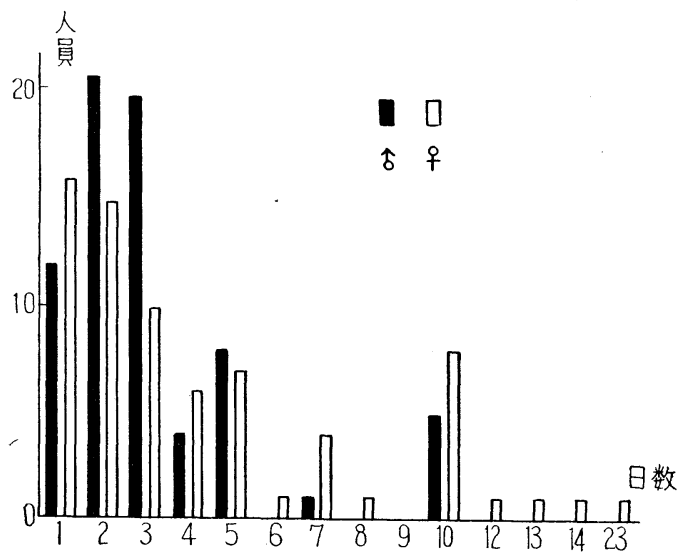

第 4 表（11一b）夜ふかし（最終時刻）

\begin{tabular}{l|r|r}
\hline & o & ᄋ \\
\hline 8 時 & 1 & 0 \\
9 & 10 & 13 \\
10 & 34 & 37 \\
11 & 21 & 18 \\
12 & 1 & 4 \\
1 & 0 & 0 \\
2 & 1 & 0 \\
不明 & 3 & 0 \\
\hline 合 計 & 71 & 72 \\
\hline
\end{tabular}

休腵中を通じて良好なる者男子 181名 $(79.4 \%)$, 女子 186名 $(79.5 \%)$ で大部分を占め, 良好でない者は男子 47 名 (20.6\%), 女子 48 名 $(20.5 \%)$ である。

養護学級児の夏季休层中の生活状況は以上のごとくで あるが, 以上のうち睡眠に関係のある起床時䘞, 就床時 刻, 睡眠時間, 午睡時間を除いた下峲, 食欲, 疾病, 水 泳, 盈踊り, 夜ふかし, 全身状態の各項につき, 体重增 加群己体重減少群より任意抽出により男女各々 30 名を選 び，とれについて体重増加者と減少者の間に生活状況に よる差異があるか否かを観察するため $\boldsymbol{x}^{2}$ 検定を行つた。 その結果注第 5 表 $(1) 〜(8)$ のでさくで，いずれも有意 の差を証明しない。

従つて以上の生活状況と体重の增減とは直接的には影 響はみられないが, 間接的には睡眠不足あるいは蓄積性 の疲労, 潜在性体力消耗となることは推測に難くない。

次に体重の増減と睡眠時間との関係を 検討するため そ，睡眠時間を午睡を含まない夜間のみの睡眠時間（以 第1図（11一b）夜ふかし（最終時刻）

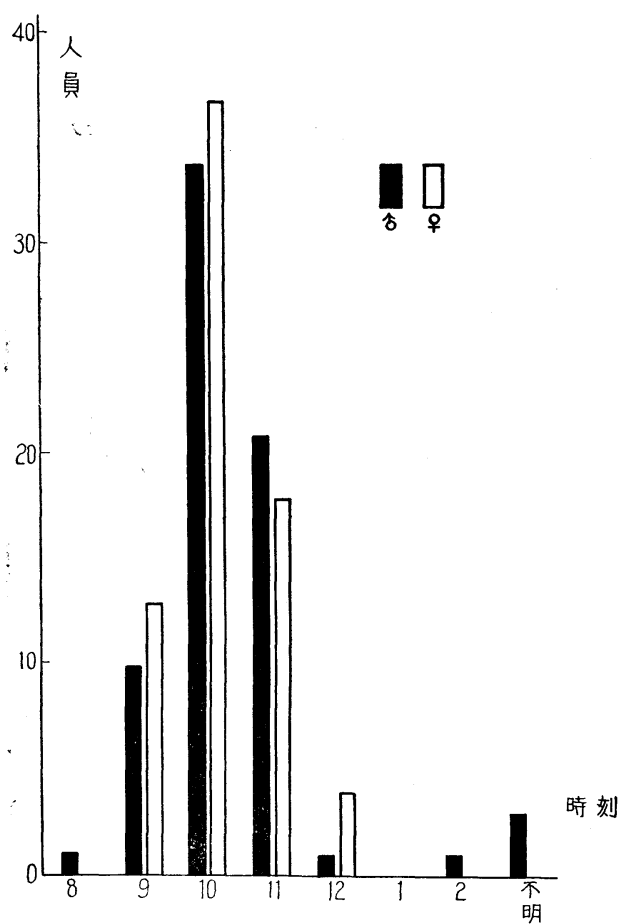

第 4 表（11一c) 夜ふかし（原因）

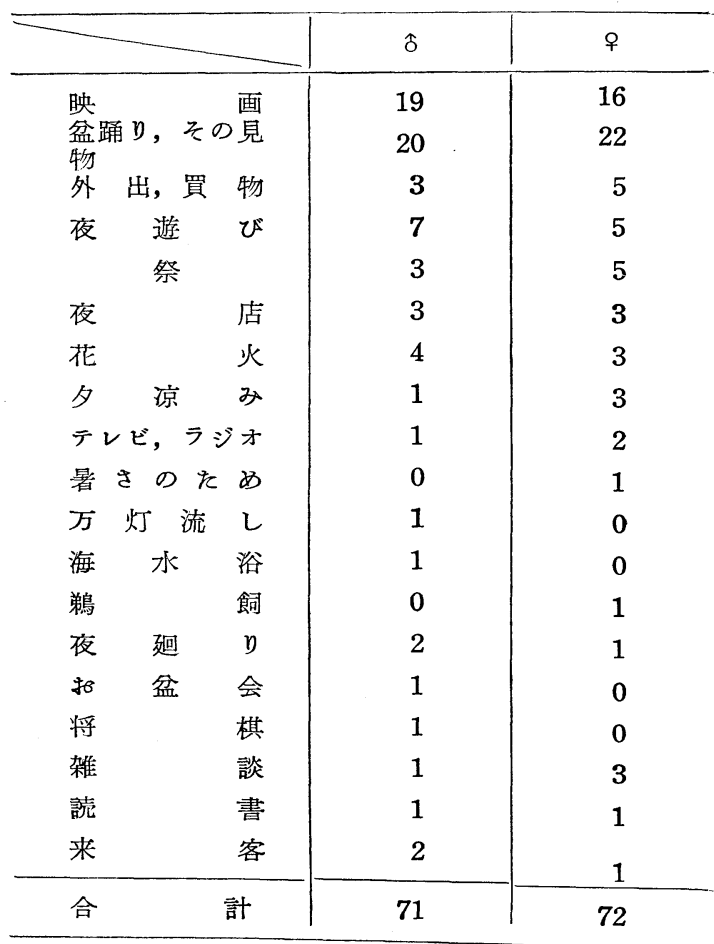


第 4 表（12）全身状留

\begin{tabular}{|c|c|c|c|c|c|}
\hline & \multicolumn{2}{|c|}{$\hat{\delta}$} & \multicolumn{2}{|c|}{ 우 } \\
\hline & & 人 員 & 百分率 & 人 員 & 百分率 \\
\hline 良 & 好 & 181 & 79.38 & 186 & 79.49 \\
\hline & p中不良 & 45 & 19.74 & 47 & 20.09 \\
\hline & 不良 & 2 & 0.88 & 1 & 0.43 \\
\hline & 計 & 47 & 20.61 & 48 & 20.51 \\
\hline 合 & 計 & 228 & 100.00 & 234 & 100.00 \\
\hline
\end{tabular}

第 1 図（12）全身状態

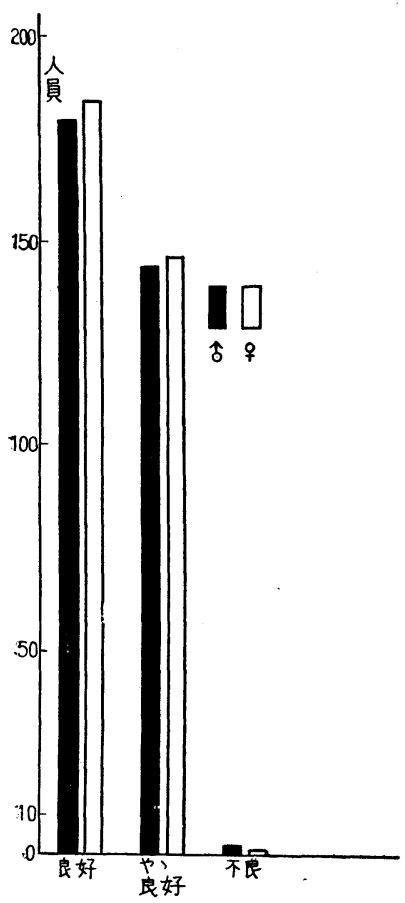

第 5 表（1）下溂

\begin{tabular}{|c|c|c|c|c|c|c|c|}
\hline \multicolumn{4}{|c|}{$\hat{o}$} & \multicolumn{4}{|c|}{ 우 } \\
\hline & あy & なし & & & Фり & なし & \\
\hline 增 加 群 & 1 & 29 & 30 & 増 加 群 & 8 & 22 & 30 \\
\hline \multirow[t]{2}{*}{ 減少群 } & 4 & 26 & 30 & 減 少 群 & 13 & 17 & 30 \\
\hline & 5 & 55 & 60 & & 21 & 39 & 60 \\
\hline \multicolumn{4}{|c|}{$\chi^{2}=0.8727 \quad \operatorname{Pr}>0.36$} & $x^{2}=1.8$ & \multicolumn{3}{|c|}{$\operatorname{Pr}>0.20$} \\
\hline
\end{tabular}

第5表（2）欲

\begin{tabular}{|c|c|c|c|c|c|c|c|}
\hline \multicolumn{4}{|c|}{$\hat{\delta}$} & \multicolumn{4}{|c|}{ 우 } \\
\hline & \multicolumn{3}{|c|}{ 良好不良 } & & \multicolumn{3}{|c|}{ 良好|不良| } \\
\hline 増 加 群 & 24 & 6 & 30 & 増 加 群 & 13 & 17 & 30 \\
\hline 減 少 群 & 19 & 11 & 30 & 減 少 群 & 10 & 20 & 30 \\
\hline & 43 & 17 & 60 & & 23 & 37 & 60 \\
\hline \multicolumn{4}{|c|}{$x^{2}=2.052 \quad \operatorname{Pr}>0.05$} & $x^{2}=0.685$ & \multicolumn{3}{|c|}{$\operatorname{Pr}>0.30$} \\
\hline \multicolumn{8}{|c|}{ 第 5 表 $(3)$ 疾 } \\
\hline \multicolumn{4}{|c|}{$\hat{\delta}$} & \multicolumn{4}{|c|}{ 우 } \\
\hline & + & - & & & + & - & \\
\hline 増 加 群 & 4 & 26 & 30 & 増 加 群 & 5 & 25 & 30 \\
\hline \multirow[t]{2}{*}{ 滅 少 群 } & 5 & 25 & 30 & 減 少 群 & 9 & 21 & 30 \\
\hline & 9 & 51 & 60 & & 14 & 46 & 60 \\
\hline \multicolumn{4}{|c|}{$\operatorname{Pr}>0.99$} & $\chi^{2}=1.49$ & \multicolumn{3}{|c|}{$\operatorname{Pr}>0.20$} \\
\hline
\end{tabular}

第 5 表（4）発 熱

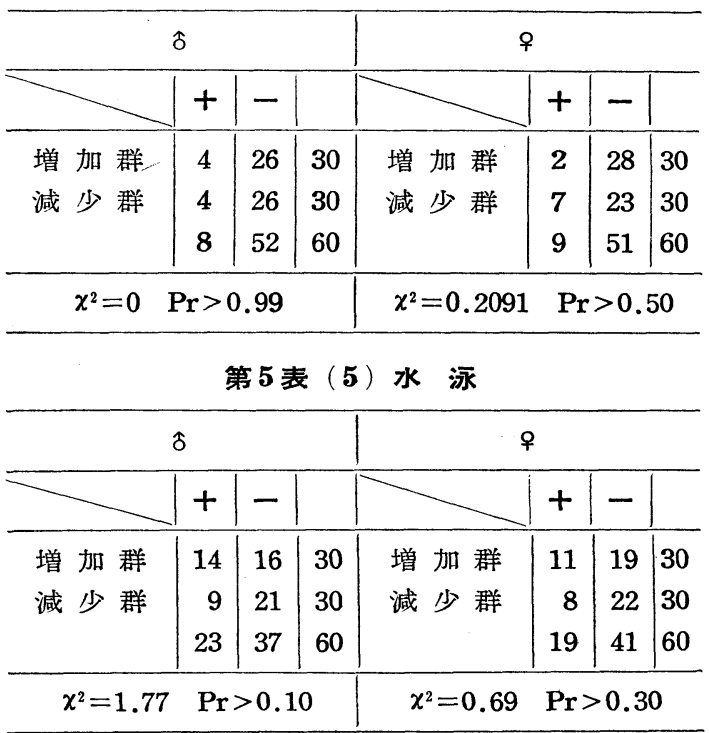

第 5 表（6）盆踊り

\begin{tabular}{|c|c|c|c|c|c|c|c|}
\hline \multicolumn{4}{|c|}{$\hat{o}$} & \multicolumn{4}{|c|}{ ㅇ } \\
\hline & Lた & しな & & & した & $\begin{array}{l}\text { しな } \\
\text { ᄂ }\end{array}$ & \\
\hline 増 加 群 & 6 & 24 & 30 & 増 加 群 & 17 & 13 & 30 \\
\hline \multirow{2}{*}{ 減 少 群 } & 7 & 23 & 30 & 減 少 群 & 19 & 11 & 30 \\
\hline & 13 & 47 & 60 & & 36 & 24 & 60 \\
\hline$\chi^{2}=0.09$ & \multicolumn{3}{|c|}{$\operatorname{Pr}>0.70^{\circ}$} & \multicolumn{4}{|c|}{$x^{2}=0.28 \quad \operatorname{Pr}>0.50$} \\
\hline
\end{tabular}


第 5 表（7）夜ふかし

\begin{tabular}{|c|c|c|c|c|c|c|c|}
\hline \multicolumn{4}{|c|}{$\hat{\delta}$} & \multicolumn{4}{|c|}{ 우 } \\
\hline & した & $\mid \begin{array}{l}\text { しな } \\
\text { 、 }\end{array}$ & & & した & $\begin{array}{l}\text { しな } \\
\text { し }\end{array}$ & \\
\hline 増 加 群 & 8 & 22 & 30 & 増 加 群 & 10 & 18 & 30 \\
\hline \multirow[t]{2}{*}{ 减 少 群 } & 12 & 18 & 30 & 減 少 群 & 12 & 20 & 30 \\
\hline & 20 & 40 & 60 & & 22 & 38 & 60 \\
\hline$\chi^{2}=1.2$ & \multicolumn{3}{|c|}{$\operatorname{Pr}>0.20$} & $\chi^{2}=0.2$ & \multicolumn{3}{|c|}{$\operatorname{Pr}>0.50$} \\
\hline
\end{tabular}

第 5 表 (8) 全身状態

\begin{tabular}{|c|c|c|c|c|c|c|c|}
\hline \multicolumn{4}{|c|}{$\hat{o}$} & \multicolumn{4}{|c|}{ 우 } \\
\hline & 良好 & 不良 & & & 良好 & 不昼 & \\
\hline 増 加 群 & 26 & 4 & 30 & 増 加 群 & 25 & 5 & 30 \\
\hline \multirow[t]{2}{*}{ 減 少 群 } & 24 & 6 & 30 & 減 少 群 & 23 & 7 & 30 \\
\hline & 50 & 10 & 60 & & 48 & 12 & 60 \\
\hline \multicolumn{4}{|c|}{$x^{2}=0.1200$} & $\chi^{2}=0.41$ & \multicolumn{3}{|c|}{$\operatorname{Pr}>0.05$} \\
\hline
\end{tabular}

下これを夜間睡眠時間とする。), 午睡時間，夜間睡眠時 間と午睡時間とを加えた 1 日の全睡眠時間 (以下これを 全睡眠時間とする。）の 3 つに分ち, 男女別に, 体重增加 群と減少群より，5\%以下の危険率て許される最少必要 標本数を满足する数として, 夜間睡眠時間については男 子89名, 女子 66 名, 全睡眠時間については男子 34 名, 女 子50名を任意抽出し（午睡時間については男子 449 名, 女子 136 名を必要とするので本調査に执いては検討がで
きないが，試みに男女各々50名を任意抽出する。)，そ れぞれの標本平均捛よび標準偏差を求めると第 6 表 (1) のしとくであり, 夜間睡眠時間については男子の体重増 加群は10時間 8 分, 減少群は 9 時間38分, 女子の增加群 は10時間15分，減少群は 9 時間32分の睡眠をとり，全睡 眠時間に括いては男子の増加群注10時間 31 分, 減少群は 9 時間59分, 女子の増加群は 10 時間 46 分, 減少群は 10 時 間 1 分亡比較的多くの睡眠時間をもち, 夜間睡眠時間沶 よび全睡眠時間についてみると，女子はいずれも男子ょ り多くの睡眠時間をもつ。

体重増加群と減少群の間に扮ける睡眠時間の比較学行 ろと, 第 6 表 (2)のごとく男女いずれも5\%以下の危険 率をもつて有意の差美証明し, 体重增加群の夜間睡眠時 間捛よび全睡眠時間は減少群より多い。

午睡時間については, 男女增加群では22分, 減少群で は21分, 女子增加群では 34 分, 減少群では 27 分でいずれ もほ涪同量の午睡を行つている。

\section{IV. 総括および考案}

所謂虚弱児の頻度については，その語義が明確ではな く, しかもその選定基準が必ずしも一定しないため諸家 の成績も区々である。

本調查に抢いては既化養護学級に編入された児童を対 象としたため, 必ずしも虚弱児の概念にあてはまるもの のみとは限らない。

第 6 表（1）睡眠時間平均 $(\overline{\mathbf{x}})$ および標準漏差（の）

\begin{tabular}{|c|c|c|c|c|c|c|c|c|c|c|}
\hline \multirow[b]{2}{*}{ 性 別 } & \multirow[b]{2}{*}{ 区 } & \multicolumn{3}{|c|}{ 睡眠時間（夜間のみ） } & \multicolumn{3}{|c|}{ 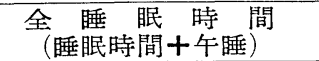 } & \multicolumn{3}{|c|}{ 午 睡 時 間 } \\
\hline & & $\overline{\mathbf{x}}$ & $\sigma$ & $\mathrm{N}$ & $\overline{\mathrm{x}}$ & $\sigma$ & $\mathrm{N}$ & $\overline{\mathbf{x}}$ & $\sigma$ & $\mathrm{N}$ \\
\hline \multirow{2}{*}{$\hat{o}$} & 体重増加群 & 10.14 & 1.98 & 89 & 10.51 & 1.73 & 34 & 0.37 & 1.33 & 50 \\
\hline & 体重減少群 & 9.63 & 1.47 & 89 & 9.99 & 1.87 & 34 & 0.35 & 1.35 & 50 \\
\hline \multirow{2}{*}{ 우 } & 体重増加群 & 10.25 & 1.83 & 66 & 10.76 & 2.43 & 50 & 0.57 & 1.58 & 50 \\
\hline & 体重減少群 & 9.54 & 2.27 & 66 & 10.01 & 2.54 & 50 & 0.45 & 1.19 & 50 \\
\hline
\end{tabular}

第 6 表（2）体重增減と睡眠時間 美の検定

\begin{tabular}{|c|c|c|c|c|c|c|c|c|}
\hline \multirow[b]{2}{*}{ 性 } & \multirow[b]{2}{*}{ 区 } & \multirow[b]{2}{*}{$\mathrm{N}$} & \multicolumn{2}{|c|}{ 睡眠時間 (夜間) } & \multicolumn{3}{|c|}{ 全睡眠時間 (睡眠時間十午睡) } & \multirow[b]{2}{*}{ (註) $+\alpha 5 \%$ と有意差あり } \\
\hline & & & $t_{s}$ & 差の㭘定| & $\mathrm{N}$ & $t_{s}$ & 差の検定 & \\
\hline$\hat{\delta}$ & $\begin{array}{l}\text { 体重増加群 } \\
\text { 体重減少群 }\end{array}$ & 89 & 2.0118 & + & 34 & 2.0496 & + & \\
\hline ㅇ & $\begin{array}{l}\text { 体重増加群 } \\
\text { 体重減少群 }\end{array}$ & 66 & 2.0412 & + & 50 & 2.0842 & + & \\
\hline
\end{tabular}


しかしてれを対象校の同一年令の総在籍児童数と比較 すると，11.6\% (男子 $11.3 \%$ ，女子 $11.8 \%$ ) にあたる。

さらに本調査対象を, 川畑8 ${ }^{8}$ の虚弱児の分類に従つ て, 疾病児童, 病弱児童, 狭義の虚弱児童の 3 つに分つ そ, 第 1 表のごとく, 結核要注意を含む病弱児童がもつ とも多く，養護学級児の約半数を占めるが，とれらの児 童は経済，設備などの面で許されるならば，それぞれ特 設の学級を編成して養護を行う必要があり, 欧米捛よび わが国の大都市では既に実施されつつある。

残りの約半数を有疾病児と狭義の虚弱児とで切半して いることになるが，有疾病児童の大部分は慢性疾患であ るが，とれもそれぞれ特設の学級を編成し，教育ととも に治療の点も加味されねばならない。

盖護学級児の約 $22.2 \%$ 占めるのが, 所謂㹨義の虚弱 児であり，てれが疾病を有するでもなくまた病弱とす る添どでもなく，水野”によれば「外来刺战に対する調 整能力が弱く, また調整能力の幅がせまいか, 調整の仕 方がまずい児童」であり，養護の面でも特異的な存在で あろろ。

さて, 夏季には健康児童でも体重増加停止ないしは減 少を示す ${ }^{10}$ が，本調查に抢いては男子の及が体重減少を 示し，女子は僅かではあるが増加の傾向にある。しかし 減少, 増加ともに推計学的に有意差はなく夏季に掠ける 体重增加の消極性を示している。

夏季休腵中における学童の生活状況の適否は, 健康児 童に掞いては勿論, 身体虚弱な要養護児童にとつてはそ の意義が重大てある。殊に戦後一般社会の風潮とともに 放染の状態にあるため, これが学童に及注す影響につい ては健康生活の面であ樑刻なものがある。著者怡養護学 級児童の生活の実態を把握し,養護の対策を得るために, 健康と深い関係のある数種目について調査を試反たので あるが，その各々について検討すると，

\section{1) 起床時刻}

睡眠と健康とが重要な関係にあることは, 既に明らか であり, 本調査によつても証明されたとてろてあるが, その睡眠については持続時間の長さの必要上, 起床扔よ び就床時刻が重要な関係を有する。

本調查では予想に反して休暇午前 6 時より 7 時 の間に起床する者が多く, アクセルキー氏試案 ${ }^{11}$ によ く一致するが, これは平常よりの養護学級児としての種 々の習慣形成の成果を示すものと思われる。しかし中に は漁村にみられたが，出漁する家族とともに，午前 4 時 より 5 時の間に起床する者のあることは, 虚弱児の場合 は注意を要する。

\section{2) 就床時刻}

睡眠時間に関係して, 健康に特に関連の梁いのは就床 時刻である。睡眠時間がたとえ必要量に達していても， 疲労の蓄積した深夜の就床が身体に重大な影響を与える ことも既に明らかである。本調査では午後 7 時より 9 時 の間が大部分であるが，乙れはアクセルキー氏試案より 1 時間遅く, 午後 10 時以後に就床する者もあることは考 慮さるべきである。

\section{3) 睡眠時間}

健康な満 6 才児に必要な生理的睡眠時間を約 11 時間と する山本，笠原，荷見に比べると，10時間前後の睡眠時 間をとる本対象では，户や不足の傾向にある。

夏季には暑熱の影響とともに, 休腵の解放感により不 規則な生活に陌ることが多いのは，後に夜ふかしの項で 明らかなどとく，社会の種々な行事が原因ともなる。

体重增加群と減少群の間には第 6 表のごとく睡眠時間 に明らかな差があるととは, 養護の面でもよき指標とな るであろう。

\section{4) 午睡時間}

前述のごとく, 夜間の睡眠時間が不足する傾向にある が，乙れは虚弱児にとつては大きな問題であり，諸家も 午睡の必要を説いているが, 養護学級児で午睡を行う者 は依然として少ない。

体重増加群と娍少群では 推計学的に 有意の 差はない が，男女とも增加群に午睡時間が多い。

さらに夜間の睡眠時間と午睡を合せた 1 日の全睡眠時 間についてみると, 体重増加群と減少群では明らかに前 者が多くの全睡眠時間をとつている。

以上の結果よりみると, 虚弱児の夜間睡眠時間の不足 を補う意味で, 1 日 1 時間程度の午睡は, 殊に夏期にお ては, 不可欠である ${ }^{311113)}$ 。ッ反応陽転, 結核性疾患, 結核要注意者を多数含む養護学級児には, 休養, 治療上 亦らも必要である。

\section{5) 下 琍}

夏季に执いて消化器系疾患の増加することは, 健康児 でも同じ傾向であるが，本調查に扮いても男子 $12.7 \% ， 。$ 女子 $7.7 \%$ に廊をみ, なかには 7 日も継続する者や, 1 日数回の者むあり，とのような者は体重減少をきたし ている。

体重増加群乞減少群では有意差は認められないが, 男 女いずれも減少群に下麻をした者が多い。

\section{6) 晨 欲}

食欲の良否は健康に重要な意義をもつであろろが，木 田 $^{15)}$, 石川 ${ }^{16)}$ の説くごとく本調査であ 食欲良好なる者 
が比較的多い。不良なる者も相当多い。

体重増加群と減少群では男女とも増加群汇良好なる者 が多いが有意の差はない。

\section{7) 疾 病}

休腵中疾病に罹患した者は男子 $27.6 \%$ ，女子 $18.4 \%$ で, 大部分の者は $1 \sim 3$ 日で恢復しているが, その疾病 の範囲は風邪, 扁桃腺炎, 腹痛, 寝冷兄, 頭痛等を主々 して非常に広範囲であり, 木田 ${ }^{17)}$, 小林 ${ }^{18)}$ の所説に一致 する。

体重增加群と減少群では疾病にかかる者が減少群に多 いが有意差はない。これは軽症の疾病を短期間経過する 者が多いとともその一因であろう。

\section{8) 発 熱}

発熱せし者は大体疾病罹患の率と添汴一致する。女子 では体重減少群に有熱者が多いが, 男女とも体重増加群 との間に有意の差はない。とれは発熱の期間も $1 \sim 3$ 日 て，大部分は中等度発熱のため直接に性重増減に響兮 ぬためであろう。

なかには37.2〜 37. $8^{\circ} \mathrm{C}$ 微熱を 30 日にわたり有する者 があり, ッ反応陽転, 結核要注意とも関係なく小児の高 体温症を思わせる ${ }^{14) 15119) 。 ~}$

\section{9) 水 泳}

長時間の水泳は紫外線の影響とともに体力消耗が甚だ しいため, 虚弱児, 殊に肺結核要注意者抢よびッ反応陽 転者には禁忌 ${ }^{38)}$ であ。

本調査では水泳しうる場所に近い者が主として水泳す るょうで, その場所に恵まれぬ者では行わぬ者が多い。

体重増加群に水泳学行つた者が多いが，減少群との間 に有意の差はない。適度の日光浴, 水泳は適応せる疾患 児掞よび体質者には勿論有効であう。

なお，一校に括いて男女とも全員体重が $1 \sim 2 \mathrm{~kg}$ 減 少した学級があり, 調查した結果, 海岸の漁港であるた め, 学童の大部分は添とんご 1 日中海で遊び, 夜は盈踊 りが 2 週間も続き就床時刻が遅いうえに，翌朝注出漁す る家族とともに早朝より起床する生活定繰返すととを知 つた。これ注虚弱児養護の点で一考を要し, 家族の認識 が必要てあることを感じた。

\section{0）盆蹁りおよび夜ふかし}

戦後の風潮として各地に盈踊りが盛んで, 学童も多数 加わつているが, 疲労性傾向の強い虚弱児荃護 ${ }^{14115)}$ の面 でもこれは考慮さるべき問題である。午前 2 時まで及ぶ 者があり，地域によつては10日から25日も続ける者もあ る。

“夜ふかし”の原因は盆踊り, 映画が大部分で，午後
10時から11時に及ぶ者が多い。

これらは成人のつくる習慣であり, 学童自らのもので はない。環境整備の技術によつては改善しろるものであ ることは注意を要する。

盈踊り，夜ふかしいずれも体重減少者に多いが，有意 の差はない。

\section{1）全身状態}

以上に述べた諸種要因の総合結果である全身状態につ いては良好な者が比較的多い。

男女をも体重減少群に全身状態不良の者が多いが，有 意の差を示すほぼではない。

\section{V. 結 論}

昭和 29 年度愛知県下 (名古屋市を除く) に捛いて養護 学級を編成する 23 校の満 6 才の児童 585 名（男子 279 名, 女子 306名) につき夏季休服前後の体重測定と休腵 中の生活状況につき調査し次の結果を得た。

1）養護学級に編入された児童は同一年令の在籍者に 対し， $11.6 \%$ (男子 $11.3 \%$ ，女子 $11.8 \%$ ) である。

2）養護学級児のうち，㹨義の虚弱児は $22.2 \%$ (男子 $24.7 \%$ ，女子 $19.9 \%$ ) であり，有疾病児は $25.1 \%$ (男子 $30.5 \%$ ，女子 $20.3 \%$ ）て，肢体不自由児拉よび結核要注 意它含む病弱な児童は $49.6 \%$ (男子 $42.6 \%$ ，女子 $55.9 \%$ ) である。

3）夏季休腵中の生活状況で体重增減に特に関係する ものは夜間の睡眠時間抽よび午睡を含めた 1 日の全睡眠 時間である。

擱筆に臨み終始御懇切なる御指導と御校閲を賜わつ た恩師水野助教授に謹んで深甚なる謝意を表し，併せて 調查に御協力戴いた 要知県教育委員会扣よび各学校の 諸先生飞感謝する。

本論交の要旨は昭和 32 年 2 月 6 日, 第 7 回名古屋市学 校保健会学術部研究発表会に挌いて発表した。

\section{交献}

1) Hecke, A. O.: The education of exceptional children. (1940).

2) Dolch, E. W. : Helping handcapped children in school. (1948).

3）文部省：身体虚弱児童生徒の健康指導の手びき， 初版, 明治四書出版株式会社, 東京 (昭28).

4) 吉田章信 : 体力測定, 第 1 版, 藤井書店, 東京 (昭18).

5) 土肥晄正 - 外 : 推計学入門, 第 2 版, 医学書院, 東京 (昭28)。

6）烟村又好・外：スネデッカー統計的方法, 第 4 版, 岩波書店, 東京 (昭29). 
7) 増山元三郎 : 実験計画法大要, 第 2 版, 学術困 書出版社, 東京 (昭25).

8) 川畑愛義：学校保健, 第 2 版, 南江堂, 東京 (昭 29).

9）水野 宏：身体虚弱児の健康指導, 初等科教育 資料（昭27）.

10）大山昭男：岐阜県公采衞生研究会々報, 第 6 号, 1 8 (昭30).

11) 橋本寛敏・外：健康生活の指導々科学, 初版, 第一出版株式会社, 東京 (昭26).

12) 山本康裕：小児科学, 第14版, 南江堂, 東京 (昭 23).
13）笠原道夫 : 臨床小览科学, 第 7 版, 克誠堂, 東京 (昭16)。

14）荷見秋次郎・外：健康教育の理論と実際, 第 4 版, 牧書店, 東京 (昭25).

15）木田交夫：虚弱・病癖児童の教育, 初版, 金子 書店, 東京 (昭24).

16) 石川道雄 : 名古屋医学, $71-5,13 \sim 46$ (昭31).

17）木田交夫・外：览科誌，53-4，13１8(昭24).

18）小林 彰・外：览科臨林, 5-1, 58 (昭27).

19）坂野好朗 - 外：览科雑誌，44-8, 1211 1224 (昭14).

（受付 : 1957 年 10 月 17 日) 